\title{
GENESIS OF LEGAL REGULATION \\ OF PUBLIC DEBT MANAGEMENT IN UKRAINE
}

\section{Olena Sudarenko ${ }^{1}$ \\ Dmytro Sydorenko ${ }^{2}$}

DOI: https://doi.org/10.30525/978-9934-26-049-0-3

Abstract. The subject of the study is public relations in the field of public debt management in Ukraine during the independence of our country, regulated by law. The purpose of the study is to conduct a retrospective study of the formation and development of legal regulation of public debt management from the time of Ukraine's independence to the present, to reflect the gradual changes in legislation that ensure the construction of an effective public debt management system, as well as establishing the legal consequences of formation of the Debt Collection Agency of Ukraine as a public debt management body. In the course of the research was used general scientific and special methods of cognition of legal phenomena and processes: dialectical, system approach, formal logical, generalization, historical and legal. It has been investigated the practice of realizing more important state bodies in the sphere of governing the state debt in Ukraine. The stage of the genesis of the legal regulation of the public debt management was designated taking into account the gradual concretization of the powers of public authorities in the specified area and the construction of an effective system of public debt management in Ukraine. It is proposed to distinguish five stages of formation and development of public debt management: Stage I: 1991-2001 - formation of Ukrainian legislation in the field of public debt; Phase II: 2002-April 2010 - further development of legislation in the field of public debt; Stage III: May 2010-2015: definition of "public debt management" appeared in Ukrainian legislation; Stage IV: 2015-2019 - beginning of European integration processes, the emergence

\footnotetext{
${ }^{1} \mathrm{Ph} . \mathrm{D}$. in Law, Associate Professor,

Kyiv National University of Trade and Economics, Ukraine

ORCID: https://orcid.org/0000-0002-4336-546X

${ }^{2}$ Postgraduate Student,

National Academy for Public Administration under the President of Ukraine, Ukraine ORCID: https://orcid.org/0000-0002-7831-948X
} 
of a new entity called the Government Commissioner for Public Debt Management, whose powers were not fixed at the level of law; introduction of the annual approval by the Government of the medium-term public debt management strategy developed by the Ministry of Finance; inclusion of norms that are typical for EU budget law, in particular, on the prohibition of exceeding $3 \%$ of the State budget deficit based on the nominal volume of gross domestic product of Ukraine. Stage V: from 2020 to the present introduction of a new model of public debt management: the emergence of a new entity called the Debt Collection Agency of Ukraine, whose powers are defined in the Budget Code; involvement of the Verkhovna Rada Committee of Ukraine on Budget Affairs in the issues of public debt management; control in the field of public debt management is exercised by the Ministry of Finance of Ukraine and the Accounting Chamber. Considering the European experience, it was changed the provisions on state participation in the capital market. It is determined that the positive results achieved by Ukraine in the field of public debt management reform are not possible without taking into account Ukraine's cooperation with the IMF and the World Bank, European community, due to European integration processes, reorientation of public loan from foreign to domestic one. Proposals for improving the legislation in this area have been developed.

\section{Introduction}

The existence of public debt and its annual increase are the realities of today's independent Ukraine. Among the reasons for the increase in public debt are the deoccupation of the territories of independent Ukraine; transition from a command and administration system to a market economy, implementation of decentralization reform, lack of professional staff to implement relevant reforms, etc. Therefore, the issue of legal regulation of public debt management is timely. One of the possible ways to solve the problem of public debt is to develop an effective legal mechanism for public debt management, creating a system of public authorities, whose powers will include only the issues of public external and internal debt management. However, the solution to this matter is not possible without a deep study of the formation and development of legal regulation of public debt management.

As for the complex scientific works of the representatives of management theory, devoted to the issues of public debt management, 
they are absent. A number of scientific works of lawyers are devoted to the issue of legal regulation of public debt, e.g. by L. Voronova, I. Zaverukha, M. Kucheryavenko, P. Patsurkivskyi and others. A comprehensive research "Legal regulation of public debt of Ukraine" was conducted by I. B. Zaverukha in 2007 [1]. During this time, there have been changes in public policy and global financial crises, so the issue of legal regulation of public debt management is relevant.

The purpose of the study is to conduct a retrospective study of the formation and development of legal regulation of public debt management from the time of Ukraine's independence to the present, to reflect the gradual changes in legislation that ensure the construction of an effective public debt management system, as well as establishing the legal consequences of the formation of the Debt Collection Agency of Ukraine as public debt management body.

To achieve this goal, several research tasks should be solved:

- to conduct a systematic analysis of the Ukrainian legislation in the field of public debt management;

- to study the powers of state bodies in the field of public debt management, their gradual specification in the legislation; to study statistical data on the ratio of public debt to GDP in Ukraine.

During the research, general-scientific and special methods of cognition of le-gal phenomena and processes were used: dialectical, system approach, formal-logical, generalization and historical and legal ones.

\section{Theoretical and legal bases of public debt in Ukraine}

In terms of the constant budget deficit, attracting additional sources of funding is one of the priorities in any country including Ukraine. Each country solves the issue of repaying the budget deficit through various legal mechanisms: the introduction of new mandatory payments to the budget, increasing revenues from existing taxes and fees by expanding the basic elements of the legal structure of the tax (tax payers, object of taxation, increase rates), reduction of budget expenditures, implementation of external and internal borrowings, etc. At the same time, the consequence of external and internal loans of the country is an increase in public debt.

"Since 1995, the legislation of Ukraine, in the concept of state and municipal credit began to include both loans taken by the state or municipal 
authorities, and loans of legal entities and individuals from the state and municipal authorities, and guarantees provided by the country to borrowers to obtain a credit. Funds borrowed by the country and municipal bodies and paid interest to legal entities (both residents and non-residents) constitute national and municipal debt. ... Funds that make up the national and municipal debt are returned to creditors from the respective budgets, so the relationship between the country (municipal bodies) is governed exclusively by law as established by the Constitution of Ukraine (part 2 of art. 92)" [2, p. 305-306].

Today, issues of government loan are regulated at the level of the Constitution of Ukraine, the Budget Code of Ukraine (hereinafter The Budget Code of Ukraine of Ukraine), the Laws of Ukraine "On Ukraine's accession to the International Monetary Fund, International Bank for Reconstruction and Development, International Finance Corporation, International Development Association and the Multilateral Investment Guarantee Agency" (hereinafter the Law "On Ukraine's Accession to the IMF"), "On Securities and the Stock Market", "On the National Bank of Ukraine", annual laws "On the State Budget", etc. Thus, according to para 49-1, part 1 of art. 2 of The Budget Code of Ukraine of Ukraine "management of public (local) debt is a set of actions related to borrowing, servicing and repayment of public (local) debt, other transactions with public (local) debt, aimed to achieve a balanced budget and optimize the debt burden" [3]. In turn, "public debt is total amount of debt obligations of the country to return received and uncovered loans (borrowings) as of the reporting date, arising from government loan" (para 20, part 1 of art. 2 of The Budget Code of Ukraine of Ukraine), and "public borrowings are operations related to the receipt of loans by the country in terms of repayment, payment, and period in order to finance public debt" (para 19, part 1 of art. 2 of The Budget Code of Ukraine of Ukraine). Also, The Budget Code of Ukraine of Ukraine contains the definitions of "local loan" (para 33, part 1 of art. 2) and "local debt" (para 35, part 1 of art. 2).

During the existence of independent Ukraine, approaches to understanding the content of public debt have changed, which has increased due to other national debts. In particular, "relations concerning the formation (issue), servicing, payback and recognition of government debt obligations in the form of government securities, other forms of 
government budget borrowings, debt obligations arising from violations of budget and tax regulations, as well as other obligations assumed by the country in accordance with current legislation and international treaties" $[1$, p. 28]. Thus, we can conclude that the legislative definition of public debt is much narrower than the scientific one.

\section{Period from 1991 to 2001}

Examining the formation and development of legal regulation of public debt management in Ukraine, it should be noted that at the beginning of the independence of our country in Ukraine there was the Law "On the budget system of Ukraine" [4]. According to Art. 19 of this Law, the expenditures of the State Budget included "expenses for servicing internal and external state debts and their repayment". "The budget deficit was covered by domestic state loans, loans from foreign countries and other financial institutions (art. 21). At the same time, the powers of the Verkhovna Rada of Ukraine included: making a decision to attract a loan to the State Budget of Ukraine in each case; regulation of the total volume of issued domestic loans within the limits of the amount of domestic public debt determined by law [4, Art. 21].

In September 1992, the Law of Ukraine "On the State Domestic Debt of Ukraine" (hereinafter the Law "On Public Debt") was adopted to implement the right of the country to be a party to relations in the field of public internal debt, in which the concept of public internal debt was defined ("term debt obligations of the Government of Ukraine in cash, which were guaranteed by all state-owned property"), the content of public internal debt and a separate article was devoted to the management of public internal debt [5]. Management of public internal debt in accordance with Art. 6 of the Law of Ukraine "On Public Debt" was carried out by the Ministry of Finance of Ukraine in the manner agreed with the NBU. At the same time, «the placement of debt obligations of the Government of Ukraine and the provision of guarantees on behalf of the Government of Ukraine was carried out by the Ministry of Finance on behalf of the Government" [6]. The parliament of Ukraine established the structure of Ukraine's public internal debt, sources and terms of repayment. However, the relevant norm, which defined the powers of the parliament, was excluded in 2005 [7].

Regarding the right of the state to participate in the state external debt, we can mention the Law of Ukraine of 03.06.1992 "On Ukraine's 
accession to the International Monetary Fund, International Bank for Reconstruction and Development, International Finance Corporation, International Development Association and the Multilateral Investment Guarantee Agency" [8] and the Decree of the President of Ukraine "On Ukraine's membership in the European Bank for Reconstruction and Development" [9]. According to the Law "On Ukraine's Accession to the IMF", the entities authorized to participate in external debt relations on behalf of the country include: 1) the Government of Ukraine, authorized to fulfill all obligations regarding Ukraine's participation in these organizations and take necessary actions to fulfill Ukraine's obligations; pay or otherwise make payments to the IMF or any one of the World Bank Group organization; receive funds for any amount to be paid or transferred to Ukraine in the course of operations in accordance with all, without exception, the articles of the IMF or the Bank; 2) The Ministry of Finance of Ukraine or another person authorized by the Government of Ukraine: to sign and deposit any documents required for the participation of the IMF; to act as a financial agent, according to Art. 5 of the Law; 3 ) the National Bank of Ukraine, authorized to issue securities necessary for Ukraine's participation in the IMF or any organization of the World Bank Group; to act as a depository bank of any amounts of the IMF and the World Bank on the territory of Ukraine. According to Art. 10 of the Law, if necessary the Ministry of Finance or the NBU issue instructions within its powers to be significant to fulfill the obligations of Ukraine.

It should be noted that the powers of the NBU in the field of public debt in accordance with para11 of art. 41 of the Law of Ukraine "On the National Bank of Ukraine" belonged only the implementation of operations to service public debt, re-lated to the placement of government securities, their redemption and payment of its income [10]. There was also a rule prohibiting the provision of direct loans in both national and foreign currency to finance state budget expenditures.

In 1996, a norm appeared in Ukrainian legislation, which determined that the control on behalf of the parliament over the formation and repayment of the internal and external debt of Ukraine is carried out by the Accounting Chamber of Ukraine Art. 98 of the Constitution of Ukraine [11], Art. 2, 22, 25 of the Law of Ukraine "On the Accounting Chamber" [12]. In the Law "On Public Debt" such rule appeared only in 2000 [6, part 4 of art. 6]. 


\section{Period from 2002 to April 2010}

In January 2002, the Budget Code of Ukraine (hereinafter Budget Code of Ukraine - 2001) came into force [13]. The innovations of Budget Code of Ukraine - 2001 include the fact that the funds to repay the principal amount of public debt are not included in budget expenditures, and they are budget expenses [13, para 14, part 1 of art. 2]. According to para 16, part 1 of art. 2 Budget Code of Ukraine - 2001, under public debt we understood the total amount of government debt, which consisted of all issued and outstanding government debt, including government debt that took effect as a result of issued loan guarantees, or obligations arised on the basis of legislation or contract. This norm also determined the debt of local self-government and the debt of the Autonomous Republic of Crimea. Also, for the first time in Ukrainian legislation in defining operations related to the receipt of budget funds on terms of repayment, payment and terms, resulted in obligations of the state, Autonomous Republic of Crimea or local government to creditors, began to use the concept of "loan" and not "borrowing" [13, para 21, part 1 of art. 2]. In our opinion, this is due to the fact that the IMF provides assistance not only with funds, but also through technical assistance and training. Chapter 3 of Budget Code of Ukraine - 2001 was devoted to the legal regulation of loan. The system of public authorities, which is authorized to make decisions on public debt and borrowing was defined in Art. 15 Budget Code of Ukraine - 2001. In particular, the powers of the Verkhovna Rada of Ukraine included the powers to determine the limits of the loan under the law on the State Budget for the corresponding year. The Government of Ukraine had the right to decide on a loan, but only within the limits and conditions specified by law (ie, the Parliament of Ukraine). On behalf of the Government, the relevant powers were exercised by the Minister of Finance or a person who exercised his powers. Thus, the Minister of Finance within these powers had the right: "in order to save money and the efficiency of their use... choose a debt holder, type of loan and borrowing currency" [13, part 3 of art. 15]. Another norm that appeared in the budget legislation for the first time was the ban on the use of emission funds of the National Bank of Ukraine as a source of financing the deficit of the State Budget of Ukraine [13, part 6 of art. 15]. The Government of Ukraine, represented by the Minister of Finance, had 
the right to provide guarantees for the fulfillment of debt obligations to economic entities, exclusively within the powers established by the law on the State Budget [13, Art. 17].

This period of formation and development of public debt management is characterized by the emergence of medium-term programs for the development of public borrowing, developed by the Government. Thus, in March 2009, the Concept of Development of the Domestic Government Securities Market of Ukraine for 2009-2013 was approved, which was aimed at reforming the primary government securities market in Ukraine, as the cost of domestic state loans exceeded the cost of external [14]. However, the concept was not properly implemented due to the global financial crisis.

\section{Period from May 2010 to 2015}

To overcome the global financial crisis, Ukraine adopts the Anti-Crisis Pro-gram approved by the Law of Ukraine of 20.05.2010 "On the State Program of Economic and Social Development of Ukraine for 2010", para 4.1.2. which was devoted to optimizing the level and structure of public debt [15]. In order to comply with the provisions of this Anti-Crisis Program, the Budget Code of Ukraine was updated and the Government of Ukraine approved the Procedure for developing a medium-term strategy for public debt management and monitoring its implementation [16]. In particular, it was envisaged that the Strategy was developed by the Ministry of Finance in agreement with the Ministry of Economy and approved by the Government within one month after the adoption of the law on the State Budget for the corresponding year. Together with the report on the implementation of the State Budget, the Ministry of Finance must develop a report on the implementation of the Strategy, which is submitted to the Government and published on the official website of the Ministry within 10 days. Thus, it supposed to introduce annual development and reporting on the implementation of the Public Debt Management Strategy. At the same time, there were no norms in The Budget Code of Ukraine regarding the report on the implementation of the strategy.

In the Budget Code of Ukraine dated 08.07.2010 (hereinafter Budget Code of Ukraine - 2010) the powers of the Cabinet of Ministers of Ukraine and the Minister of Finance were defined almost in accordance with the norms of Budget Code of Ukraine - 2001 [17]. At the same time, the 
authority to determine the conditions of state loan, type, currency, term and interest rate of state loan was assigned to the Government of Ukraine (part 1 of art. 16). Also in Budget Code of Ukraine - 2010 there was no separate rule that would clearly define the powers of public authorities in the field of public debt management. These powers should have been derived from the analysis of the norms of Budget Code of Ukraine - 2010 . The innovations of this code included the fact that the Minister of Finance in agreement with the NBU, in accordance with Part 8 of Art. 16 Budget Code of Ukraine - 2010 acquired the right "within the current budget period to carry out on a competitive basis and/or through auctions placement of temporarily free funds of the single treasury account and foreign currency accounts of the state budget on deposits or by purchasing such funds until the end of the current budget period" [17]. According to part 12 of art. 17 Budget Code of Ukraine - 2010 the Minister of Finance was authorized to sell at the open auctions the right to demand repayment of overdue more than three years debts to the state on loans (borrowings) raised by the state or under state guarantees, as well as loans from the budget, in the manner prescribed by the Government.

This period is also characterized by changes in the NBU's powers over public debt. Thus, in 2010 the NBU acquired the right to send a request to the Government, ministries and other central executive bodies to provide information that had an impact on the balance of payments, public debt and payment schedule for it [18]. Expanded list of entities through which the NBU was prohibited from providing loans to the state, in particular, it was deprived of the right to buy securities issued by the Government, state institution, other legal entity whose property was state-owned [19, art. 54]. Since 2012, the powers of the NBU also include the establishment of direct correspondent relations with foreign depositories in order to perform public debt management functions and bailment of foreign bonds in external depositories [19, art. 42].

\section{Period from 2015 to 2019}

The next stage of development of relations in the field of public debt manage-ment is characterized by several important points, in particular, during this period the Association Agreement between Ukraine began to be applied, on the one hand, and, on the other, from 27.06.2014 89 to be applied with the 
European Union, European Atomic Energy Community and their Member States [20], which was ratified by Ukraine [21]. In particular, Art. 347 of the Association Agreement provides cooperation in the field of public finance management by improving the exchange of experience and information on budget planning and execution, and the condition of public debt.

Another important fact of this period is the creation of a special subject of public debt management called the Government Commissioner for Public Debt Management of Ukraine [22]. The Government Commissioner for Public Debt Management reports to the Minister of Finance [22, para. 2]. However, the powers of this entity are not defined at the level of the law, with the exception of the Law "On Ukraine's accession to the IMF", which is a violation of part 2 art. 19 of the Constitution of Ukraine [11].

This period is characterized by the specification of the powers of the Account-ing Chamber as a body of state external financial control, which monitors not only the effectiveness of operations on government internal and external loans, govern-ment guarantees, servicing and repayment of government and state-guaranteed debt, but also examines the effectiveness of public debt management and state-guaranteed debt [23, p. 11].

In our opinion, it is also important, especially taking into account the European integration processes, to include in the Budget Code of Ukraine the norms that are typical for EU budget law. Thus, the state budget deficit for each year of the medium term (in Ukraine budget planning takes place for the next planning year and two following budget periods) may not exceed $3 \%$ of the projected nominal gross domestic product of Ukraine for the year. This indicator should be observed in the law on the State Budget [3, Art. 14]. Considering the pandemic caused by COVID-19, the relevant regulations of the Budget Code have been suspended for 2020 and 2021. [24; 25]

Consolidation of the provisions on the development of a medium-term public debt management strategy at the level of the Budget Code took place in 2018 [26]. Thus, the Strategy should be formed by the Ministry of Finance considering the indicators defined by the Budget Declaration and the Law on the State Budget of Ukraine. The Government has the authority to approve this strategy within two months from the date of entry into force of the Law on the State Budget of Ukraine. Subsequently, the parliament took into account the deadlines for drafting the Budget Declaration and the deadline for submitting the budget execution report, so the deadline for 
approval of the strategy by the Government was changed to "annually, no later than June 1 of the year preceding the planned one" [27].

\section{Period from 2020 to the present}

The next stage in the development of relations in the field of legal regulation of public debt management begin in 2020. Thus, on 01.01.2020 the norms of the Budget Code of Ukraine came into force, which provide the creation of a new state body in the field of public debt management the Debt Collection Agency of Ukraine [27]. However, in accordance with paragraph 3 of the Law of Ukraine "On Amendments to the Law of Ukraine "On the State Budget of Ukraine for 2020", the powers of the Government of Ukraine to establish and ensure the activities of the central executive body were temporarily suspended until 01.01.2021 due to the COVID-19 pandemic, which implemented the state budget policy in the field of public debt management and state-guaranteed debt [24]. According to Art. 15-1 of The Budget Code of Ukraine of Ukraine, the activities of the Debt Collection Agency are directed and coordinated by the Government through the Minister of Finance of Ukraine. The model of public debt management through a separate body (agency) successfully operates in such countries of the European Union as Austria, Belgium, the Netherlands, Germany, Sweden and others [28].

Thus, from 2020, a new model of public debt management in Ukraine was envisaged: the parliament in the law on the state budget determines the limits of public loan during the budget period; the Government of Ukraine determines the basic conditions for state loan; The Minister of Finance instructs the Debt Collection Agency of Ukraine to carry out relevant activities, and the Head of the Debt Collec-tion Agency of Ukraine exercises the right to carry out state internal and external loans. At the same time, the Government of Ukraine, in agreement with the Verkhovna Rada Committee on Budget, determines the terms of transactions with public debt carried out in the current budget period in excess of 5\% of public debt at the end of the previous budget period. Chairman of the Debt Collection Agency of Ukraine, according to part 5 of art. 16 of The Budget Code of Ukraine of Ukraine has the right to "undertake obligations, on behalf of Ukraine, related to the implementation of loans and transactions (for the effective management of public debt, state guarantees), including the 
refusal of sovereign immunity in possible disputes over such obligations" [3]. The Debt Collection Agency of Ukraine has been empowered to place temporarily free funds of the single treasury account and foreign currency accounts of the state budget on deposits or by purchasing government securities with subsequent return of such funds by the end of the current budget period. Also, the powers of the Debt Collection Agency include the preparation of an annual report on the results of public debt management and state-guaranteed debt and its publication on its official website no later than April 1 of the year following the reporting [3, part 3 of art. 15-1]. The Ministry of Finance of Ukraine is authorized to exercise control over public debt management (by determining the organizational and methodological principles of such management and systematic analysis of the results of such management), as well as the Accounting Chamber (public external financial control (audit)). The Debt Collection Agency also manages public debt, maintains relevant registers, and the Ministry of Finance of Ukraine is authorized to manage local debt, with the right to maintain relevant registers and apply measures of influence, in the form of a ban on new agreements for the next three years under Part 7 of Art. 74 Budget Code of Ukraine of Ukraine.

On July 1, 2021, the Law of Ukraine "On Capital Markets and Organized Commodity Markets" will come into force, which, taking into account the norms of European legislation in this area, specifies the powers of entities participating in the capital market [29]. In particular, such entities include the state, represented by the central executive body authorized to implement state budget policy in the field of public debt management and state-guaranteed debt (Debt Collection Agency of Ukraine), the National Bank of Ukraine [29, Art. 6]. The Debt Collection Agency of Ukraine is authorized to decide on the terms of placing (issue, redemption, conversion and repayment) of government bonds, treasury obligations of Ukraine and government derivatives [29, parts 7-9 of Art. 16, parts 3-4 of Art. 20, part 4 of Art. 30]. With regard to the placement of domestic government bonds, the National Bank of Ukraine and the Debt Collection Agency of Ukraine participate in these legal relations. In particular, the functions of the NBU include the functions of public debt service related to the placement of domestic government loans, their repayment and payment of income. The National Bank of Ukraine is authorized to develop a document that 
would determine the relevant actions of the subjects of legal relations in the field of servicing domestic government bonds, and the powers of the Debt Collection Agency include the approval of this act [29, part 8 of art. 16]. As for government derivatives and treasury obligations of Ukraine, the NBU does not have the appropriate powers, decisions are made by the Debt Collection Agency.

It should be noted that the Law of Ukraine "On Capital Markets and Organized Commodity Markets" reduces the range of entities authorized to issue bonds of local loans. According to part 3 of Article 16 and Article 74 of the Budget Code of Ukraine, regional councils are included to the entities that have the right to make external borrowings (by obtaining credits (loans) from international financial organizations) and local domestic borrowings in addition to the Verkhovna Rada of the Autonomous Republic of Crimea and city councils. We believe that part 2 of Article 15 of the Law of Ukraine "On Capital Markets and Organized Commodity Markets" to be brought in line with the Budget Code and to determine the regional councils among the entities authorized to decide on the issue of local debt bonds.

According to statistics, the public debt of Ukraine is growing, so that as of December 31, 2015, the public and state-guaranteed debt of Ukraine amounted to 65.51 billion US dollars, at 31.12.2020 it already amounted to 90.26 billion US dollars [30]. According to the official data of the Ministry of Finance of Ukraine, since 2016 in Ukraine there has been a "tendency to reduce the ratio of public debt to GDP". If in 2014 the ratio of public debt to GDP was $60 \%$, in $2016-69 \%$, then in $2019-44.3 \%$ [31]. According to the Medium-Term Public Debt Management Strategy for 2019-2022, approved by the Resolution of the Cabinet of Ministers of Ukraine dated 05.06.2019 № 473, it is assumed that at the end of 2022 this ratio will not exceed $43 \%$ [32]. Ukraine was able to achieve corresponding positive changes in the amount of public debt due to improved legislation in the field of public debt management, close cooperation with the International Monetary Fund, the World Bank and other international financial organizations, European integration processes and reorientation of public borrowing from foreign to domestic.

It can be assumed that it has become possible to achieve positive changes in the ratio of public debt to GDP due to the creation of the Government Commissioner for Public Debt Management and its qualified actions in 
performing advisory and consultative functions on public debt management. The Government Commissioner for Public Debt Management, within the scope of its powers, carries out activities in the field of "preparation of proposals to improve the structure of public debt, by studing and relevant transactions with public debt, including exchange, issue, purchase, redemption and sale of public debt; preparation and participation in negotiations with creditors (including with the relevant authorities of foreign states and international organizations) on public debt management" [22].

During 2020, the powers in the field of management were exercised by the "Ministry of Finance of Ukraine with the Government Commissioner. The Ministry of Finance has managed to attract capital from international and local investors to the state budget to cope with a sharp increase in the budget deficit from $2.1 \%$ to $7.5 \%$ of GDP", said the international publication GlobalMarkets, which covers the annual meeting of the IMF and World Bank. In 2020, Ukraine was awarded in the nomination "Best Public Debt Management Office in Central and Eastern Europe" [33].

\section{Conclusions}

The creation of an effective system of public debt management as an objective process of development of our country took place in stages. In our opinion, our country has gone through five stages of development of legal regulation of public debt management:

Stage I: 1991-2001 - formation of Ukrainian legislation in the field of public debt. The state bodies authorized to participate in public debt relations included the Parliament, Government, Ministry of Finance and the National Bank. The Accounting Chamber was assigned to control functions in the field of public debt. There was a transfer of powers to establish the structure, sources and terms of repayment of public domestic debt from parliament to the Government;

Stage II: 2002 - April 2010: - further development of legislation in the field of public debt, for the first time the concept of "budget expenditures»" was singled out, which was much broader than the concept of "expenses"; began to use the terms "loan" instead of "borrowing" and "credit"; the emergence of a direct ban on the use of emission funds of the NBU to repay the state budget deficit. Emergence of medium-term programs for the development of government domestic loan. During this stage there 
appeared concretization of the powers of the Parliament, the Government, the Ministry of Finance and the NBU in the field of public debt;

Stage III May 2010-2015: emergence in Ukrainian legislation of the definition "public debt management", the possibility of using temporarily free budget funds in the field of public debt; the absence of a separate rule that would clearly define the powers of public authorities in the field of public debt management, the relevant powers had to be derived on the basis of a systematic analysis of the legislation; clear consolidation at the level of the norms of the Budget Code of the Government's powers regarding the conditions of state loan, type, currency, term and interest rate;

Stage IV: 2015-2019 - beginning of European integration processes, the emergence of a new entity called the Government Commissioner for Public Debt Management, whose powers were not fixed at the level of the law; introduction of the annual approval by the Government of the medium-term public debt management strategy developed by the Ministry of Finance. During this stage there was concretization of powers of the Accounting Chamber as a body of state external control. The inclusion of norms that are typical for EU budget law, in particular, on the prohibition of exceeding 3\% of the State budget deficit based on the nominal volume of gross domestic product of Ukraine.

Stage V: from 2020 to the present - introduction of a new model of public debt management: emergence of a new entity - the Debt Collection Agency of Ukraine, whose powers are defined in the Budget Code, involvement of the Verkhovna Rada Committee on Budget Affairs in Public Debt Management; control in the field of public debt management is exercised by the Ministry of Finance of Ukraine and the Accounting Chamber.

The powers of the Debt Collection Agency of Ukraine and the National Bank of Ukraine in the capital market on the placement of government bonds, treasury obligations of Ukraine and government derivatives are defined by the new Law of Ukraine "On Capital Markets and Organized Commodity Markets", which takes into account European legislation.

In order to eliminate the collision between the rules of Part 2 of Article 15 of the Law "On Capital Markets and Organized Commodity Markets" and Part 3 of Article 16 and Article 74 of the Budget Code of Ukraine, we consider it is necessary to amend Article 15 of the Law and, among the authorized entities to decide on the issue of local debt bonds, to determine the regional councils. 
The effectiveness of this model of public debt management has yet to be stud-ied, as due to the COVID-19 pandemic, the establishment of the Debt Collection Agency of Ukraine was suspended for 2020 and the regulations of the Law of Ukraine "On Capital Markets and Organized Commodity Markets" will come into force starting from 01.07.2021. From the scientific point of view, it is interesting to study the possibility of using digital securities of states in the relations of public debt management.

\section{References:}

1.Zaverukha, I.B. (2007) Problemy pravovoho rehuliuvannia derzhavnoho borhu Ukrainy. [Problems of legal regulation of State Debt]: (Doctors thesis), Ivan Franko Lviv State University, 360 p. (accessed 15 February 2021). (in Ukrainian)

2. Voronova L. (2006) Finansove pravo Ukrainy: Pidruchnyk. Kyiv: Pretsedent; Moia knyha [Financial law of Ukraine: textbook], 448 p. (accessed 15 February 2021). (in Ukrainian)

3. Biudzhetnyi kodeks Ukrainy vid 08.07.2010 № 2456-VI (persha redaktsiia). Data onovlennya: 01.01.2021 [The Budget Code of Ukraine: The Law of Ukraine on June 21, 2001 № 2542-III, Loss of force on January 1, 2011, on the basis № 2456-VI]. Retrieved from: https://zakon.rada.gov.ua/laws/show/2542-14\#Text (accessed 15 February 2021). (in Ukrainian)

4. Pro biudzhetnu systemu: Zakon Ukrainy vid 05.12.1990 № 512-XII (vtratyv chynnist na pidstavi Biudzhetnoho kodeksu 24.07.2001 № 2452-III). Data onovlennya: 24.07.2001 [On the budget system of Ukraine: The Law of Ukraine on December 5, 1990 № 512-XII, Loss of force on July 24, 2001, on the basis 2542-III] Retrieved from: https://zakon.rada.gov.ua/laws/show/512-12\#Text (accessed 15 February 2021) (in Ukrainian)

5. Pro derzhavnyi vnutrishnii borh Ukrainy: Zakon Ukrainy vid 16.09.1992 № 2604-XII (persha redaktsiia zakonu) (vtratyv chynnist na pidstavi Zakonu vid 07.07.2011 № 3614-VI). Data onovlennya: 07.08.2011 [On State Internal Debt of Ukraine: The Law of Ukraine on September 16, 1992 № 2604-XII, first version, Loss of force on July 07, 2011, on the basis 3614-VI]. Retrieved from: https://zakon.rada.gov.ua/laws/show/2604-12/ed19920916\#Text (accessed 15 February 2021). (in Ukrainian)

6. Pro derzhavnyi vnutrishnii borh Ukrainy: Zakon Ukrainy vid 16.09.1992 № 2604-XII (vtratyv chynnist na pidstavi Zakonu vid 07.07.2011 № 3614-VI). Data onovlennya: 07.08.2011 [On State Internal Debt of Ukraine: The Law of Ukraine on September 16, 1992 № 2604-XII, Loss of force on July 07, 2011, on the basis 3614-VI]. Retrieved from: https://zakon.rada.gov.ua/laws/show/2604-12\#Text (accessed 15 February 2021). (in Ukrainian)

7. Pro vnesennya zmin do Zakonu Ukrainy "Pro Derzhavnyi biudzhet Ukrainy na 2005 rik" ta deiakykh inshykh zakonodavchykh aktiv Ukrainy: Zakon Ukrainy vid 25.03.2005 № 2505-VI. Data onovlennya: 24.10.2020 [On Amendments to the Law of Ukraine "On the State Budget of Ukraine for 2005" and Certain Other 
Legislative Acts of Ukraine: The law of Ukraine of March 25, 2005 № 2505-IV]. Retrieved from: https://zakon.rada.gov.ua/laws/show/2505-15\#Text (accessed 15 February 2021). (in Ukrainian)

8. Pro vstup Ukrainy do Mizhnarodnoho valiutnoho fondu, Mizhnarodnoho banku rekonstruktsii ta rozvytku, Mizhnarodnoi finansovoi korporatsii, Mizhnarodnoi asotsiatsii rozvytku ta Bahatostoronnoho ahentstva po harantiiakh investytsii: Zakon Ukrainy vid 03.06.1992 № 2402-XII. Data onovlennya: 24.04.1992 [On Ukraine's Entry into International Currency Fund, International Bank for Reconstruction and Development, International Finance Corporation, International Association for Development, Multilateral Ivestment Guarantee Agency: The law of Ukraine on June 3, 1992 № 2402-XII]. Retrieved from: https://zakon.rada.gov.ua/laws/show/2402-12\#Text (accessed 15 February 2021). (in Ukrainian)

9. Pro chlenstvo Ukrainy v Yevropeiskomu banku rekonstruktsii ta rozvytku: Ukaz Prezydenta Ukrainy vid 14.07.92 № 379/92 [On Ukraine’s membership in the European Bank for Reconstruction and Development: The Decree of the President of Ukraine on July 14, 1992 № 379/92]. Retrieved from: https://zakon.rada.gov.ua/ laws/show/379/92\#Text (accessed 15 February 2021). (in Ukrainian)

10. Pro Natsionalnyi bank Ukrainy: Zakon Ukrainy vid 20.05.1999 № 679-XIV (persha redaktsiia). Data onovlennya: 01.01.2021 [On the National Bank of Ukraine: The Law of Ukraine on May 20, 1999 № 679-XIV, first version]. Retrieved from: https://zakon.rada.gov.ua/laws/show/679-14/ed19990520\#Text (accessed 15 February 2021). (in Ukrainian)

11. Konstytutsiia Ukrainy vid 28.06.1996 № 254к/96-VR. Data onovlennya: 01.01.2020 [The Constitution of Ukraine: The Law of Ukraine on June 28, 1996 № 254к/96-VR]. Retrieved from: https://zakon.rada.gov.ua/laws/show/254к/ 96-вр\#Text (accessed 15 February 2021). (in Ukrainian)

12. Pro Rakhunkovu palatu: Zakon Ukrainy vid 11.07.1996 № 315-96/VR (vtratyv chynnistna pidstaviZakonu vid 02.07.2015 № 576-VIII). Data onovlennya: 09.08.2015 [On Accounting Chamber, The Law of Ukraine on July 11, 1996 № 315 96/VR]. Retrieved from: https://zakon.rada.gov.ua/laws/show/315/96-вp?find=1\&text=борг\# Text (accessed 15 February 2021). (in Ukrainian)

13. Biudzhetnyi kodeks Ukrainy vid 21.06.2001 № 2543-III (vtratyv chynnist na pidstavi Biudzhetnoho kodeksu 08.07.2010 № 2456-VI). Data onovlennya: 01.01.2021 [The Budget Code of Ukraine: The Law of Ukraine on June 21, 2001 № 2543-III, Loss of force on July 8, 2010, on the basis-2456-VI]. Retrieved from: https://zakon.rada.gov.ua/laws/show/2542-14\#Text (accessed 15 February 2021). (in Ukrainian)

14. Pro skhvalennya Kontseptsii rozvytku vnutrishnoho rynku derzhavnykh tsinnykh paperiv Ukrainy na 2009-2013: Rozporiadzhennya Kabinetu Ministriv Ukrainy vid 25.03.2009 № 316-r [On approval of the Concept of development of the domestic market of government securities of Ukraine for 2009-2013: The Order of the Cabinet of Ministers of Ukraine on March 25, 2009 № 316-r]. Retrieved from: https://zakon.rada.gov.ua/laws/show/316-2009-p\#Text (accessed 15 February 2021). (in Ukrainian) 
15. Pro Derzhavnu prohramu ekonomichnoho i sotsialnoho rozvytku Ukrainy na 2010 rik: Zakon Ukrainy vid 20.05.2010 № 2278-VI [On the State Program for Economic and Social Development of Ukraine for the Year 2010: The Law of Ukraine on May 20, 2010 № 2278-VI]. Retrieved from: https://zakon.rada.gov.ua/ laws/show/2278-17?find $=1 \&$ (accessed 15 February 2021). (in Ukrainian)

16. Pro zatverdzhennia Poryadku rozroblennia Serednostrokovoi stratehii upravlinnia derzhavnym borhom i kontroliu za yii realizatsiieiu: Postanova Kabinetu Ministriv Ukrainy vid 27.10.2010 № 978 (vtratyla chynnist na pidstavi 883-2018-p vid 30.10.2018) Data onovlennya: 30.10.2018 [On approval of the Procedure for development of the Medium-term strategy of public debt management and control over its implementation: The Resolution of the Cabinet of Ministers of Ukraine on October 27, 2010 № 978, Loss of force on October 30, 2018, on the basis - 883-2018-r]. Retrieved from: https://zakon.rada.gov.ua/laws/ show/978-2010-п\#Text (accessed 15 February 2021). (in Ukrainian)

17. Biudzhetnyi kodeks Ukrainy vid 08.07.2010 № 2456-VI (persha redaktsiia). Data onovlennya: 01.01.2021 [The Budget Code of Ukraine, The Law of Ukraine on June 21, 2001 № 2456-IV, First version]. Retrieved from: https://za-kon.rada.gov.ua/laws/show/2456-17/ed20100708\#Text (accessed 15 February 2021). (in Ukrainian)

18. Pro vnesennya zmin do deiakykh zakonodavchykh aktiv Ukrainy shchodo diialnosti Natsionalnoho banku Ukrainy: Zakon Ukrainy vid 09.07.2010 № 2478-VI. Data onovlennya: 01.01.2011 [On Amendments to Certain Legislative Acts of Ukraine Concerning the Activity of the National Bank of Ukraine: The Law of Ukraine on July 9, 2010 № 2478-VI]. Retrieved from: https://zakon.rada.gov.ua/ laws/show/2478-17\#Text (accessed 15 February 2021). (in Ukrainian)

19. Pro Natsionalnyi bank Ukrainy: Zakon Ukrainy vid 20.05.1999 № 679-XIV. Data onovlennya: 01.01.2021 [On the National Bank of Ukraine: The Law of Ukraine on May 20, 1999 № 679-XIV]. Retrieved from: https://zakon.rada.gov.ua/ laws/show/679-14?find=1\&text=емісі\#Text (accessed 15 February 2021). (in Ukrainian)

20. Uhoda pro asotsiatsiiu mizh Ukrainoiu, z odniiei storony, ta Yevropeiskym Soiuzom, Yevropeiskym spivtovarystvom $z$ atomnoi enerhii i yikhnimy derzhavamy-chlenamy, z inshoi storony 27.06.2014. Data onovlennya: 30.11.2015 [Association Agreement between Ukraine, of the one part, and the European Union, the European Atomic Energy Community and their Member States, of the other part]. Retrieved from: https://zakon.rada.gov.ua/laws/show/984_011/ find?text $=\% \mathrm{E} 1 \% \mathrm{EE} \% \mathrm{~F} 0 \% \mathrm{E} 3 \#$ Text (accessed 15 February 2021). (in Ukrainian)

21. Pro ratyfikatsiiu Uhody pro asotsiatsiiu mizh Ukrainoiu, z odniiei storony, ta Yevropeiskym Soiuzom, Yevropeiskym spivtovarystvom $\mathrm{z}$ atomnoi enerhii $\mathrm{i}$ yikhnimy derzhavamy-chlenamy, z inshoi storony: Zakon Ukrainy vid 16.09.2014 № 1678-VII [On the ratification of the Association Agreement between Ukraine, of the one part, and the European Union, the European Atomic Energy Community and their Member States, of the other part: The Law of Ukraine on September 16, 2014 № 1678-VII]. Retrieved from: https://zakon.rada.gov.ua/laws/show/1678-18\#n2 (accessed 15 February 2021). (in Ukrainian) 
22. Pytannya Uriadovoho upovnovazhenoho z pytan upravlinnia derzhavnym borhom: Postanova Kabinetu Ministriv Ukrainy vid 11.03.2015 № 88 [Issue of the Government Commissioner for Public Debt Management: The Resolution of the Cabinet of Ministers of Ukraine on March 11, 2015 № 88]. Retrieved from: https://zakon.rada.gov.ua/laws/show/88-2015-п\#Text (accessed 15 February 2021). (in Ukrainian)

23. Pro Rakhunkovu palatu: Zakon Ukrainy vid 02.07.2015 № 576-VIII. Data on-ovlennya: 01.01.2021 [On Accounting Chamber, The Law of Ukraine on July 2, 2015 № 576-VIII]. Retrieved from: https://zakon.rada.gov.ua/laws/ show/576-19?find $=1 \&$ text=борг\#Text (accessed 15 February 2021). (in Ukrainian)

24. Pro vnesennya zmin do Zakonu Ukrainy "Pro Derzhavnyi biudzhet Ukrainy na 2020 rik“: Zakon Ukrainy vid 13.04.2020 № 553-IX. Data onovlennya: 15.01.2021 [On modification of the Law of Ukraine "On the State budget of Ukraine for 2020": The Law of Ukraine on April 13, 2020 № 553-IX]. Retrieved from: https://zakon.rada.gov.ua/laws/show/553-20\#n83 (accessed 15 February 2021). (in Ukrainian)

25. 25 Pro Derzhavnyi biudzhet Ukrainy na 2021 rik: Zakon Ukrainy vid 15.12.2020 № 1082-IX. Data onovlennya: 31.01.2021 [On the State budget of Ukraine for 2021: The Law of Ukraine on December 15, 2020 № 1082-IX]. Retrieved from: https://zakon.rada.gov.ua/laws/show/1082-20\#n133 (accessed 15 February 2021). (in Ukrainian)

26. Pro vnesennia zmin do Biudzhetnoho kodeksu Ukrainy shchodo zaprovadzhennia serednostrokovoho biudzhetnoho planuvannia: Zakon Ukrainy vid 06.12.2018 № 2646-VIII [On amendments to the Budget Code of Ukraine regarding the introduction of medium-term budget planning: The Law of Ukraine on December 6, 2018 № 2646-VIII]. Retrieved from: https://zakon.rada.gov.ua/ laws/show/2646-19\#n31 (accessed 15 February 2021). (in Ukrainian)

27. 27.Pro vnesennya zmin do Biudzhetnoho kodeksu Ukrainy: Zakon Ukrainy vid 14.11.2019 № 293-IX. Data onovlennya: 18.04.2020 [On amendments to the Budget Code of Ukraine: The Law of Ukraine on November 14, 2019 № 293-IX]. Retrieved from: https://zakon.rada.gov.ua/laws/show/293-20\#n43 (accessed 15 February 2021). (in Ukrainian)

28. Ekonomichna pravda: Minfin poiasnyv funktsii novostvorenoho Borhovoho ahentstva. 14.11.2019 (2021) [The Ministry of Finance explained the functions of the newly created Debt Agency]. Retrieved from: https://www.epravda.com.ua/ news/2019/11/14/653711/ (accessed 15 February 2021). (in Ukrainian)

29. Pro vnesennia zmin do deiakykh zakonodavchykh aktiv Ukrainy shchodo sproshchennia zaluchennia in-vestytsii ta zaprovadzhennia novykh finansovykh instrumentiv: Zakon Ukrainy vid 19.06.2020 № 738-IX [On amendments to some legislative acts of Ukraine to simplify the attraction of investments and the introduction of new financial instruments: The Law of Ukraine on on June 19, 2020 №738-IX]. Retrieved from: https://zakon.rada.gov.ua/laws/show/738-20\#Text (accessed 15 February 2021). (in Ukrainian)

30. Derzhavnyi borh ta harantovanyi derzhavoiu borh (2021). Ofitsiinyi veb sait Ministerstva finansiv Ukrainy [State Debt and State Guaranteed Debt, Official 
website of Ministry of Finance of Ukraine]. Retrieved from: https://www.mof.gov.ua/ uk/derzhavnij-borg-ta-garantovanij-derzhavju-borg/ (accessed 15 February 2021). (in Ukrainian)

31. Borhova statystyka. Dynamika spivvidnoshennia Derzhavnoho borhu do VVP, 2014-2019 (2021). Ofitsiinyi veb sait Ministerstva finansiv Ukrainy [Debt Statistics 2014-2019, Official website of Ministry of Finance of Ukraine]. Retrieved from: https://www.mof.gov.ua/uk/borgovi-pokazniki-st/ (accessed 15 February 2021). (in Ukrainian)

32. Pro zatverdzhennya Serednostrokovoi stratehii upravlinnia derzhavnym borhom na 2019-2022 roky: Postanova Kabinetu Ministriv Ukrainy vid 05.06.2019 № 473 [On approval of the Medium-Term Public Debt Management Strategy for 2019-2022: The Resolution of the Cabinet of Ministers of Ukraine on June 5, 2019 № 473]. Retrieved from: https://zakon.rada.gov.ua/laws/show/473-2019\%D0\%BF\#Text (accessed 15 February 2021). (in Ukrainian)

33. Ukraina peremohla $\mathrm{V}$ nominatsii «Naikrashchyi ofis $\mathrm{z}$ upravlinnia derzhavnym borhom v Tsentralnii ta Skhidnii Yevropi» vid mizhnarodnoho vydannia GlobalMarkets Awards. 15.10.2020 (2021). Ofitsiinyi veb sait Ministerstva finansiv Ukrainy [GlobalMarkets Awards 2020 Names Ukraine the Debt Management Office of the Year in CEE, Official website of Ministry of Finance of Ukraine]. Retrieved from: https://mof.gov.ua/uk/news/ukraina_peremogla_v nominatsii naikrashchii_ofis_z_upravlinnia derzhavnim borgom_v tsentralnii

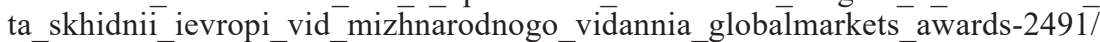
(accessed $1 \overline{5}$ February 2021). (in Ukrainian) 